\title{
SYMPOSIUM ON THE BIDEN ADMINISTRATION AND THE INTERNATIONAL LEGAL ORDER
}

\author{
A NEW ERA FOR TRADE?
}

\author{
Judith Goldstein
}

Trade policy decisions have direct, and almost immediate, effects on American jobs and wages. As result, historically, commercial policy has been highly partisan and closely associated with constituent demands. From this perspective, the post-World War II years were anomalous: trade policy was bipartisan and de-politicized. Due to rapid growth in the U.S. economy, those hurt by imports were easily re-employed, dampening the growth of a proprotection coalition in either party. This facilitated a U.S.-led expansion of trade under the umbrella of commonly accepted international rules. In the last decades of the twentieth century, however, this pro-trade consensus began to unravel. While U.S. exports continued to thrive, the growth of regional and global value chains and the emergence of East Asian manufacturing giants caused job dislocation and a bifurcation of the U.S. economy around a skill premium. The Trump administration's response was to externalize these problems onto U.S. trading partners. The Biden administration needs a different strategy. Even though the Democratic party has been critical of aspects of the multilateral regime, Biden must re-connect with the international community. The United States should strive to be a better partner in the World Trade Organization (WTO), resist the capricious use of trade law, and rebuild a competitive domestic economy.

This will not be easy. Biden faces an unusual political landscape in setting trade policy. Anti-globalism is a Baptist-bootlegger coalition of the left and right. The left worries about wage pressures because of competition from nations with fewer labor protections; the right opines that the United States has become too dependent on foreign production, resulting in a loss of sovereignty. When projected into arguments about law, the left advocates the reform and expansion of trade rules to address social concerns, while the right advocates for a decoupling of the United States from international agreements and a general dismissal of international law. No matter President Biden's personal views on trade, this coalition will constrain his policy options, including within his own party.

As well as facing a formidable anti-globalist coalition, President Biden needs to confront the remnants of Trump-era policies. Trump came to office insisting that earlier presidents had made bad trade deals and that the United States was disadvantaged by the W'TO. While the center of the Republican party never embraced this anti-internationalist sentiment, Trump and his trade team deviated markedly from the traditional Republican party position on free markets and instead advocated for a far more muscular, nationalist trade policy. Biden's task is to rebuild relationships with trading partners who have come to see the United States as an unreliable ally. But he will need to balance this more conciliatory urge with the fundamentals of the U.S. economy and his promise to upend dependence on Asian value chains and produce more at home.

* Janet M. Peck Professor of International Communication and Professor of Political Science, Stanford University, Stanford, California, United States.

(C) Judith Goldstein 2021. This is an Open Access article, distributed under the terms of the Creative Commons Attribution licence (http://creativecommons.org/licenses/by/4.0/), which permits unrestricted re-use, distribution, and reproduction in any medium, 


\section{Biden and the Trading Regime}

Trump has left the WTO in disarray. The United States-Mexico-Canada Agreement (USMCA) is still largely aspirational. Executive branch authority to negotiate certain types of international agreements-Trade Promotion Authority (TPA) - is about to expire. What should Biden do?

First, Biden must dramatically shift the tone in America's interactions with W'TO members. In working with the WTO, the United States should seek alliances on core issues, from who leads the secretariat to how to rebuild the dispute-settlement system. Biden will immediately need to address reforms of the Appellate Body (AB) and, in particular, the rebuilding of automatic, binding WTO dispute settlement. The current stalemate in the AB is a result of a refusal to name judges, but the problem is bigger: the lack of a dispute-settlement system undermines the legitimacy of an organization that has, on the whole, served U.S. interests.

This task will not be easy: Biden well understands that the United States cannot go alone against China, and that the W'TO can be his agent, but many in his party see the W'TO as a threat to U.S. interests. What would an effective approach entail? Biden could insist that China relinquish its "developing country" status, advocate for policies that make it easier to adjudicate Chinese violations, and attempt to integrate bilateral trade agreements into the WTO system. It is doubtful that the United States could gain congressional approval to join the new Trans-Pacific Partnership (TPP), ${ }^{1}$ and the United States is a mere spectator in China's quest to integrate Asian trade via the Regional Comprehensive Economic Partnership (RCEP). But Biden could push to integrate these agreements into the WTO system, which would give the United States some oversight.

There are other ways the United States could smooth trade relations in the WTO. Biden could address disputes that festered during the Trump years, in particular the dispute between Boeing and Airbus. As well, Biden could endorse rule reforms that would strengthen the organization. These include rules ranging from how to deal with subsidies - which are currently too narrowly defined to address the situation in China, demand too high a standard of evidence for those who wish to challenge them, and provide inadequate remedies - to cooperation on a global steel agreement to reduce excess global production capacity. While some of these initiatives have been under discussion, Biden should move quickly and take advantage of the "good will" created by his election by pushing ahead with these reforms as well as a carbon border tax agreement, something that was unimaginable under his predecessor.

Second, the Biden administration needs to vigorously support the USMCA. Many of its provisions come from earlier TPP negotiations and are a needed modernization of the trade agreement. The dispute-settlement system, the hallmark of the original deal, remains essentially the same and indeed was strengthened through the creation of a list of panelists, which the United States had earlier blocked. Biden should attempt to enforce the parts of the agreement that the Democratic party applauded: the provisions on wages, rules of origin, and the environmental accords.

Third, if Biden wants to have a voice in trade negotiations moving forward, he will need to get Congress to renew TPA. TPA allows the White House to negotiate trade deals that are credible by subjecting passage in Congress to strict rules and timelines that do not permit amendments, but this authority expires in June 2021. With a Democratic House and a Democratic president, the chances of approval are now significantly greater than under the Trump administration. Receiving new TPA will allow Biden to complete a number of skeleton trade deals that are on the table, the most visible being a new agreement with the post-Brexit United Kingdom.

\footnotetext{
${ }^{1}$ The collapse of the TPP exemplifies the operation of a classic left-right coalition. While the agreement is consistent with Biden's world view, getting the TPP through Congress will be difficult. But, given the Trump years, the backlash may actually provide Biden with more freedom on this than expected.
} 


\section{The Domestic Market}

Trump arrived in office claiming that the trading system was systemically unfair to the United States. As evidence, Trump pointed to the tariff bindings of America's trading partners, to dispute-settlement findings, and to the absence of sanctions against China. ${ }^{2}$ Philosophically, he abhorred international law as an unfair constraint on American interests and vigorously responded with unilateral tariff hikes. Biden must take a big step back from these policies. What would that mean?

First, the United States must rescind a majority of the border protections imposed by Trump. To the distress of the international community, the Trump years revealed that international trade law is a weak constraint. The WTO is filled with exceptions or cut-outs that allow nations to deviate from obligations. The WTO was never intended to be a straightjacket and members were allowed to protect their markets if warranted. Trump egregiously took advantage of this under-specification of limits on national autonomy. Acting unilaterally, he mobilized a set of domestic legal rules that resulted in an explosion of tariffs, directed at both allies and China.

In raising tariffs, Trump relied on authority granted in earlier U.S. trade legislation, in particular, Section 232 of the Trade Expansion Act of 1962 and Section 301 of the Trade Act of $1974 .{ }^{3}$ Section 232 provides for a national security exception to tariff bindings; what constitutes national security, however, is underspecified, and Trump applied an extraordinarily broad conception of the term. At the same time, the Trump administration re-activated Section 301, a statute that was created to defend U.S. exporters and has a controversial relationship with WTO law. ${ }^{4}$ These two statutes can be contrasted with traditional exceptions permitted under WTO rules, namely antidumping duties (AD), countervailing duties (CVD), and safeguards. While the WTO never forbade the use of these statutes, members were discouraged from unilateral responses to trade-related injury.

From the earliest days of his administration, Trump ignored international norms on border measures. He imposed a 25 percent tariff on imported steel and a 10 percent tariff on aluminum on national security grounds. These tariffs hurt Canada, the European Union, Mexico, and Japan but had no effect on China. ${ }^{5}$ According to economist Anne Krueger, they cost Americans US\$900,000 per year per job "saved." Yet, employment in the steel sector continued to decline and steel exports did not rise. To address the trade imbalance with China, Trump used Section 301 authority to raise tariffs on Chinese products from 3.5 percent to over $20 \%$ percent $^{7}$ And as a warning to America's other trading partners, the administration created a "hit list" of potential violators under Section 301. The residual effects are that our trading partners view the United States as an unreliable partner, prices are higher at home, and industry has been emboldened to lobby for exceptions. In other words, Trump's tariff policy did little to spur employment and instead led to retaliatory duties and a rise in industry rent-seeking.

Second, Biden has to address the effects of Chinese market power. During the Trump years, China became increasingly assertive in a range of trade-related issues, from setting regulatory standards to refusing to agree to

\footnotetext{
2 A tariff binding is the multilateral "ceiling" rate for a product's tariff that is guaranteed by international agreement.

${ }^{3}$ Section 232 of the Trade Expansion Act of 1962 allows the imposition of tariffs on the recommendation of the Secretary of Commerce, if an article is imported in a quantity or under a circumstance that threatens U.S. national security. Section 301 of the Trade Act of 1974, last revised in 2018, authorizes the president to take all appropriate actions to obtain the removal of impediments to U.S. exporters and investors in foreign markets.

${ }^{4}$ The capricious use of Section 301 helped catalyze reform of the multilateral dispute-settlement system itself in 1989 and has since become a "renegade" trade remedy.

${ }^{5}$ U.S. steel imports from China are small at about $2 \%$ of the national total.

${ }^{6}$ Anne Krueger, Trump’s Backward March on Trade, Project Syndicate (Jan. 20, 2020).

${ }^{7}$ The U.S. tariff schedule on Chinese goods is complex, as products are on different lists and some are subject to exclusion.
} 
intellectual property protections. Trump's response was to use access to the U.S. market as a cudgel to force Chinese compliance. This strategy failed not only to aid U.S. manufacturers but even worse, ceded international leadership to the Chinese. The United States is now playing catch up.

Symptomatic of this failure is the dramatic rise in farm payments. In what is known as the phase-one agreement of February 2020, China promised specific amounts of purchases of U.S. farm products. The commitments were never met and the Chinese export market continued to dwindle. To retain farm community political support, Trump created an expensive system of side payments. One of Biden's first political decisions on the China front will be whether to continue the level of U.S. farm aid that Trump allocated to make up for the lost sales to China that resulted from his trade policy. The United States has paid out more than US $\$ 34$ billion in farm aid, despite the fact that the WTO rules allow only approximately US $\$ 19$ billion in support. ${ }^{8}$ The European Union, Australia, India, and Brazil have raised this issue in the WTO's agricultural committee, but their challenges meant little to Trump. Biden can use them as cover to reduce the payments, but he may want to move slowly. In any event, he would be better served to focus on the source of the problem, that is, excess capacity and reduced market access in China.

Getting an agreement from China on this issue will not be easy. Biden will need to find common ground for negotiations on these issues amid a tense relationship, reflecting not only the anti-China rhetoric of the Trump years but also the Chinese regime's increasingly aggressive stance on security and human rights issues. Biden has regularly described China not as an enemy but as a strategic competitor; this more conciliatory position may help, both in bilateral talks and within the WTO, where the United States will need allies to collectively pressure the Chinese government. While encouraging talks, Biden should not be overly hasty on removing Chinese tariffs. The tariffs could be convenient in creating both an incentive for China to come to the table and something the United States can exchange in return for a larger deal.

Third, Biden needs to invest in American productive capacity. In doing that, he must reconcile the use of internal and external policy. Given the number of domestic and international stakeholders affected by his decisions, this will not be an easy task. "I promise you this," Biden said while discussing government procurement; "every single product, every single contract let [sic] will be only let [sic] to a company or a firm that makes it in America from beginning to end." 9 On this issue, Biden and Trump sound indistinguishable. How can Biden balance his internationalist urges with his domestic concerns?

To better prepare American workers for international competition, Biden must reinvigorate the Trade Adjustment Assistance (TAA) programs. Although in existence since 1962, TAA has been under-financed and of limited reach in its task of supporting the adjustment of uncompetitive workers and industry. The lack of such support has been America's Achilles heel, spurring resistance to internationalism. Biden should use and expand the TAA infrastructure; given the geography of job loss, this is one of the few programs that could engender bipartisan support. Re-training, relocation support, tuition assistance, and health care subsidies are all policies that could be available under the TAA framework. As well, Biden should expand TAA to include other policies, including apprentice training programs, low-cost loans for entrepreneurial activities, and a jobs placement program, if necessary, via executive action.

To assure a more competitive industrial platform and fend off protectionist pressures, Biden needs a politically salient "industrial policy." Specifically, Biden needs to harness government resources to build industrial capacity through targeted subsides and assured government purchases, akin to what was done in Operation Warp Speed. Which industries should garner support? Biden has indicated a willingness to assist health-related and "green"

${ }^{8}$ Our Most Read: As Reshoring Talk Increases, Some Push Back, Inside Trade (Sept. 29, 2020).

9 Trump and Biden Hit Home Stretch, Focus on Trade-Impacted States, World Trade Online (Oct. 13, 2020). 
production; the needs of these new industries will have to be balanced against the interests of the more traditional, and often unionized, sectors of the economy. Adjudicating between producers is a political mine field, leading Douglas Irwin to suggest the creation of an interagency study group. ${ }^{10}$ The alternative would be to appoint an industry czar, playing a role akin to John Kerry's on climate change, to interface between industry groups and the administration.

But in rebuilding the economy from within, Biden cannot ignore the existing infrastructure of domestic protectionism. Remedies that protect the U.S. market from the unfair trade practices of other nations are deeply rooted in American law. While there are aspects of the U.S. adjudication process that have raised concern at the WTO, most notably zeroing in $\mathrm{AD}$ cases, the laws are quite specific, and industry lawyers are adept at knowing what cases will get relief. ${ }^{11}$ Biden will have to moderate the use of these remedies, less via the control of the independent bureaucracy and more by working with industries to moderate the flow of petitions. Biden may well find that bureaucratic protectionism increases, especially in $\mathrm{AD}$ and CVD cases, even as he is trying to mend his relationship with U.S. trading partners.

\section{Moving Forward}

In sum, President Biden is facing a divided Congress, angry allies, a K-shaped recovery, and a generalized antipathy toward globalization. America's trading partners have lost faith in U.S. leadership, and the United States has lost faith in multilateralism. Years of trade liberalization without robust domestic adjustment system has undermined the pro-globalization coalition. These challenges are daunting. To address them, Biden should pursue a number of measures:

- First, Biden should be less of a crusader for free trade and more of a "healer in chief." Trade policy needs to return to being "low" politics, delegated to experts and focused on regulatory issues rather than deeper liberalization.

- Second, Biden must rescind all the tariffs on U.S. allies and avoid future policies that export market adjustment costs onto America's trading partners.

- Third, Biden should recommit to multilateralism and become a better partner to the WTO.

- Fourth, the administration needs a bilateral trade rapprochement with China and simultaneous agreement within the WTO for more extensive oversight of Chinese trade practices.

- Fifth, Biden should push pro-growth job policies via a more robust set of industrial support policies.

Trade policy has been erratic over the last four years and has cost America jobs and productive capacity. Instead of seeing U.S. interests as at odds with those of our trading partners, President Biden should mend fences. This is the surest way to grow the U.S. economy.

${ }^{10}$ Douglas A. Irwin, Memo to the Biden Administration on How to Rethink Industrial Policy, Peterson Inst. Int'L Econ. (Oct. 20, 2020).

11 Zeroing is a method of price determination in antidumping cases. 